\title{
Enhancement of enzyme activity and stability by poly $(\gamma$-glutamic acid)
}

\author{
Eun-Hye Lee ${ }^{1}$, Takashi Tsujimoto ${ }^{1}$, Hiroshi Uyama ${ }^{1}$, Moon-Hee Sung ${ }^{2,3}$, Kwang Kim ${ }^{4}$ and Seiki Kuramitsu ${ }^{4}$ \\ The effects of poly( $\gamma$-glutamic acid) ( $\gamma \mathrm{PGA})$, a water-soluble poly(amino acid), on the enzyme activity and stability have been \\ investigated. The activity of carbonic anhydrase (CA) was distinctly improved in the presence of $0.30-2.0 \% \gamma \mathrm{PGA}$ at $\mathrm{pH} 7$. \\ $\gamma \mathrm{PGA}$ was also effective to enhance the activity of lipase and $\alpha$-amylase. $\gamma \mathrm{PGA}$ efficiently suppressed denaturation of the \\ enzyme by the thermal treatment and repeated freeze-thaw process. The interaction of $\gamma P G A$ and CA was investigated by using \\ fluorescence probe-labeled protein. The Michaelis-Menten kinetics on the CA-catalyzed hydrolysis of $p$-nitrophenyl acetate in the \\ absence or presence of $\gamma$ PGA were performed, which demonstrated that the enhancement of the CA activity by $\gamma$ PGA is ascribed \\ to the increase of the catalytic constant $\boldsymbol{k}_{\text {cat }}$.
}

Polymer Journal (2010) 42, 818-822; doi:10.1038/pj.2010.71; published online 18 August 2010

Keywords: $\mathrm{CA}$; enhancer; enzyme activity; $\gamma \mathrm{PGA}$; stabilizer

\section{INTRODUCTION}

There has been an increasing interest in enzyme engineering from practical aspects owing to environmentally benign catalysis of enzymes under mild reaction conditions with regard to temperature, pressure and $\mathrm{pH}$, which often lead to remarkable energy efficiency. Enzymes are useful for bioremediation of polluted water and contaminated soil, improvement of cleaning efficiency of detergents, and production of biofuel, and highly expected as potential practical applications in industry. ${ }^{1,2}$ For these applications of enzymes, the loss of enzyme activity in use is often observed, which sometimes restricts the industrial applications. In addition, the activity is influenced by temperature and chemical environments such as $\mathrm{pH}$ and salt type.

For purification and isolation of enzymes, lyophilization is widely used; however, the repeated freeze-thaw process often induces denaturation of the enzyme due to multiple stresses. Once enzymes fold to their native form, they are generally stable under mild conditions. On the other hand, most of unstable enzymes readily form aggregations even under mild conditions to lose their activity. Therefore, protection of enzymes against environmental stresses is required in industrial applications.

So far, there have been various methods to stabilize enzymes ${ }^{3-6}$ and enhance enzyme activity; for the latter, enzyme immobilization, ${ }^{4-7}$ chemical modification of enzymes ${ }^{8-10}$ and medium engineering ${ }^{11,12}$ were reported. Polyols, ${ }^{13}$ saccharides, ${ }^{13,14}$ surfactants ${ }^{15}$ and watersoluble polymers, such as poly(vinyl alcohol), ${ }^{15}$ poly(ethylene glycol) (PEG), ${ }^{15-17}$ and poly(ethyleneimine), ${ }^{18}$ acted as enzyme stabilizer or enhancer of enzyme activity. Furthermore, many researchers have attempted to improve enzyme stability and to enhance enzyme activity by rational design and in vitro evolution of enzymes. ${ }^{19-23}$ In most cases, however, protein biocatalysts showing the desired properties have not been obtained.

$\operatorname{Poly}(\gamma$-glutamic acid) ( $\gamma$ PGA) is a water-soluble biopolymer consisting of $\mathrm{D}^{-}$or $\mathrm{L}-\gamma$-glutamate unit. $\gamma \mathrm{PGA}$ is produced by several Bacillus species such as Bacillus anthracis, Bacillus licheniformis and Bacillus subtilis. ${ }^{24-28} \gamma \mathrm{PGA}$ is substantially biodegradable, nontoxic to humans and even edible; thus, its industrial applications have been extensively studied from industrial standpoints. Its multifunctionalities made it a promising biopolymer for various uses such as health foods, moisturizers in cosmetics, chelating agents in wastewater treatment, hydrogels for environmental, agricultural and biomedical applications. ${ }^{26-30}$

This study deals with the effects of $\gamma$ PGA on the enzyme activity and stability. $\gamma$ PGA is an amino-acid polymer via peptide linkage; thus $\gamma$ PGA will be interacted with enzyme polypeptides to influence the enzyme action. In this study, carbonic anhydrase (CA), lipase and $\alpha$ amylase were selected as target proteins, which are easy to assay their activity; they are often used as a model enzyme to examine the stability and improvement of the activity. ${ }^{15,31,32}$

\section{EXPERIMENTAL PROCEDURE}

Materials

$\gamma$ PGAs (sodium salt form, molecular weight: 50 and $500 \mathrm{kDa}$ ) were commercial products of BioLeaders Corp. (Daejeon, Korea). CA from bovine erythrocytes, Amano lipase AK from Pseudomonas fluorescens, $\alpha$-amylase type VI-B from porcine pancreas, $p$-nitrophenyl acetate $(p N P A)$, fluorescein isothiocyanate (FITC) isomer I and phosphate-buffered saline ( $\mathrm{pH} 7.4)$ were purchased from Sigma-Aldrich (St Louis, MO, USA). 1-Anilinonaphthalene-8-sulfonate was a product of Tokyo Chemical Industry (Tokyo, Japan). Potassium dihydrogen

${ }^{1}$ Department of Applied Chemistry, Graduate School of Engineering, Osaka University, Osaka, Japan; ${ }^{2}$ Department of Bio and Nanochemistry, Kookmin University, Seoul, Korea; ${ }^{3}$ BioLeaders Corp., Daejeon, Korea and ${ }^{4}$ Department of Biological Sciences, Graduate School of Science, Osaka University, Osaka, Japan

Correspondence: Professor H Uyama, Department of Applied Chemistry, Graduate School of Engineering, Osaka University, Yamadaoka 2-1, Suita, Osaka 565-0871, Japan. E-mail: uyama@chem.eng.osaka-u.ac.jp

Received 10 March 2010; revised 9 June 2010; accepted 5 July 2010; published online 18 August 2010 
phosphate $\left(\mathrm{KH}_{2} \mathrm{PO}_{4}\right)$, potassium monohydrogen phosphate $\left(\mathrm{K}_{2} \mathrm{HPO}_{4}\right)$, tris(hydroxymethyl)aminomethane (Tris), calcium chloride $\left(\mathrm{CaCl}_{2}\right)$, p-nitrophenyl propionate ( $p$ NPP) and acetonitrile were products of Wako Pure Chemical Industries (Osaka, Japan). Sodium chloride $(\mathrm{NaCl})$ was purchased from Nacalai Tesque (Kyoto, Japan). All solvents and reagents were used without further purification.

\section{Preparation of $\gamma$ PGA-enzyme mixtures and assays of enzyme activity}

$\gamma$ PGA and CA were separately dissolved in $25 \mathrm{~mm}$ potassium phosphate buffer ( $\mathrm{pH}$ 7.0) and mixed, and then the resulting mixture was further diluted by this buffer to $0.030 \mathrm{mg} \mathrm{ml}^{-1}$ concentration of CA. The concentration of $\gamma$ PGA was adjusted according to each experiment. The activity of CA was determined by assay of the $p$ NPA hydrolysis. The assay started by mixing $10 \mu \mathrm{l}$ of $100 \mathrm{~mm}$ $p \mathrm{NPA}$ in acetonitrile and $1.0 \mathrm{ml}$ of the above CA solution with different $\gamma \mathrm{PGA}$ concentration for $20 \mathrm{~s}$ at $25^{\circ} \mathrm{C}, 33-35$ and the amount of the resulting p-nitrophenol was monitored from the absorbance change at $400 \mathrm{~nm}$ as a function of time by U-2810 ultraviolet-visible spectrophotometer (Hitachi, Tokyo, Japan). Michaelis-Menten kinetics were performed in the concentration range of $p$ NPA from $2.5 \times 10^{-4}$ to $1.0 \times 10^{-2} \mathrm{M}$ in the fixed concentration of CA as $0.030 \mathrm{mg} \mathrm{ml}^{-1}$. The kinetic parameters, $K_{\mathrm{m}}$ and $k_{\text {cat }}$, were determined from Lineweaver-Burk plots of $1 / v$ versus $1 /[\mathrm{S}] .^{36}$

In the case of lipase, a solution of $0.030 \mathrm{mg} \mathrm{ml}^{-1}$ lipase including $0.50 \%$ of $\gamma$ PGA, $150 \mathrm{~mm} \mathrm{NaCl}, 1.36 \mathrm{~mm} \mathrm{CaCl}_{2}$ and $13 \mathrm{~mm}$ Tris- $\mathrm{HCl}$ was prepared and the $\mathrm{pH}$ of the solution was adjusted at $\mathrm{pH}$ 8.0. For the heat treatment, the sample was kept at $55,70,85$ or $95^{\circ} \mathrm{C}$ for $10 \mathrm{~min}$ and then cooled at $25^{\circ} \mathrm{C}$ for $20 \mathrm{~min}$. The lipase activity was determined by monitoring the amount of $p$-nitrophenol formed by the hydrolysis of $p \mathrm{NPP}$ at $25^{\circ} \mathrm{C} . .^{37,38}$

For $\alpha$-amylase, a solution of $0.060 \mathrm{mg} \mathrm{ml}^{-1} \alpha$-amylase including $0.50 \%$ of $\gamma \mathrm{PGA}$ and $0.10 \mathrm{~m}$ of 4-morpholinepropanesulfonate was prepared and the $\mathrm{pH}$ of the solution was adjusted at $\mathrm{pH}$ 6.9. For the heat treatment, the sample was kept at $37,50,65$ or $80^{\circ} \mathrm{C}$ for $20 \mathrm{~min}$ and then cooled at $25^{\circ} \mathrm{C}$ for $20 \mathrm{~min} . \alpha-$ Amylase activity was determined according to the modified protocol of EnzChek Ultra Amylase Assay Kit (Molecular Probes, Eugene, OR, USA).

\section{Preparation of FITC-CA}

To a $5.0 \mathrm{mg} \mathrm{ml}^{-1} \mathrm{CA}$ solution in $0.10 \mathrm{M}$ sodium carbonate bicarbonate $(\mathrm{pH}$ 9.0), a $1.0 \mathrm{mg} \mathrm{ml}^{-1}$ FITC solution in the same buffer was added under gentle stirring and kept at $25^{\circ} \mathrm{C}$ for $2 \mathrm{~h}$ under dark conditions. The resulting FITClabeled CA (FITC-CA) was purified by gel filtration chromatography $(2.0 \times 30 \mathrm{~cm})$ of Sephadex G-100 (Pharmacia Fine Chemicals, Uppsala, Sweden) with phosphate-buffered saline ( $\mathrm{pH} 7.4)$ as eluent. ${ }^{39,40}$ Fluorescence spectra were recorded by F-2500 fluorescence spectrophotometer (Hitachi).

\section{Freeze-thaw process}

A $1 \mathrm{ml}$ volume of a $0.030 \mathrm{mg} \mathrm{ml}^{-1}$ CA solution without or with $1.0 \% \gamma \mathrm{PGA}-50$ was transferred into $1.5 \mathrm{ml}$ Eppendorf tube and frozen at $-25^{\circ} \mathrm{C}$. The frozen mixture was thawed at room temperature. This process was repeated in several cycles and the enzyme activity was measured.

\section{RESULTS AND DISCUSSION}

\section{Effect of $\gamma$ PGA on the activity of CA}

At first, the activity of CA in the presence of $0.50 \%$ various watersoluble polymers such as $\gamma$ PGA with molecular weight of $50 \mathrm{kDa}$, hyaluronic acid (HA), PEG, and alginic acid (ALG) was examined in a potassium phosphate buffer of $\mathrm{pH} 7.0$ (Figure 1). In this study, the concentration of CA was fixed as $0.030 \mathrm{mg} \mathrm{ml}^{-1}$ and $p \mathrm{NPA}$ was used as substrate for the activity assay of CA. Without CA, the $p$ NPA hydrolysis hardly proceeded in the presence of $\gamma \mathrm{PGA}$, strongly suggesting that $\gamma$ PGA did not induce the $p$ NPA hydrolysis (data not shown). Among the water-soluble polymers examined, only $\gamma$ PGA improved the activity of CA. In the case of hyaluronic acid, the activity was almost the same as that without the additive, and the presence of PEG and ALG reduced the enzymatic activity. These results suggest that $\gamma \mathrm{PGA}$ acts as an enhancer of enzyme activity in a simple mixing process.

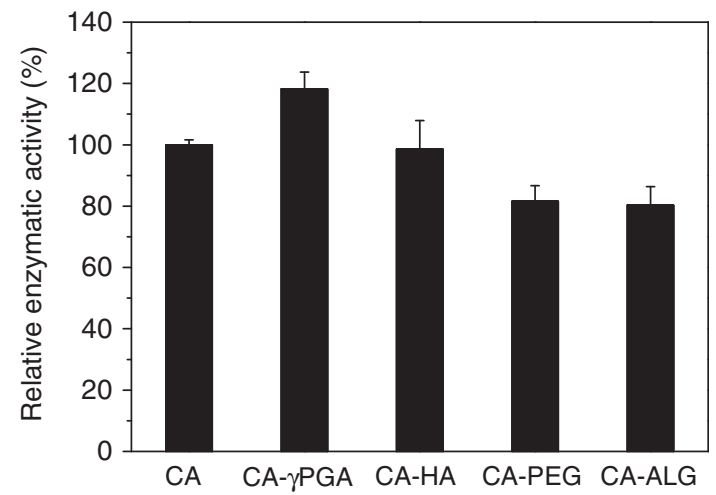

Figure 1 Relative activity of CA in the presence of $0.50 \%$ water-soluble polymers $(n=3)$

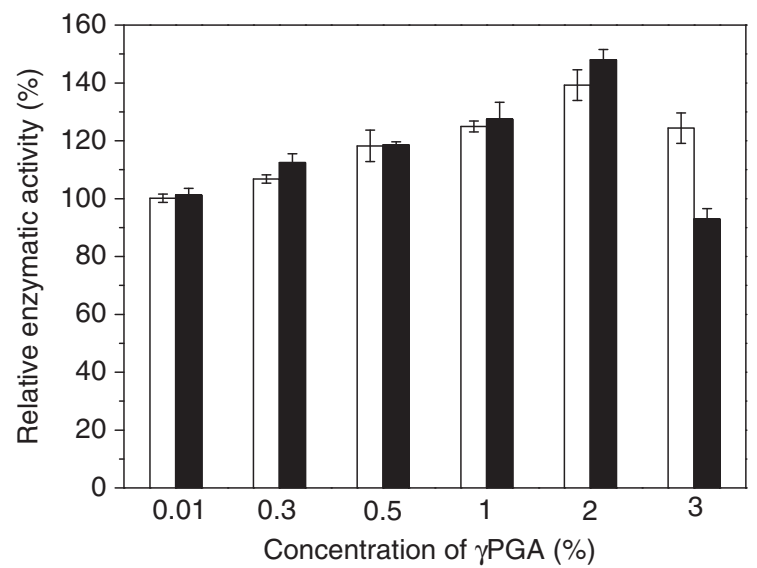

Figure 2 Effects of concentration and molecular weight of $\gamma P G A$ on the activity of CA. White and black bars represent the activity of CA in the presence of $\gamma$ PGA-50 and $\gamma$ PGA-500, respectively $(n=15)$.

Figure 2 shows the effects of the concentration and molecular weight of $\gamma$ PGA on the activity of CA. $\gamma$ PGAs with molecular weight of 50 and $500 \mathrm{kDa}(\gamma \mathrm{PGA}-50$ and $\gamma$ PGA-500, respectively) were used. When the concentration of $\gamma$ PGA was very low $(0.010 \%)$, the improved effect was hardly observed. In the concentration range of $0.3-2.0 \%$, the activity increased as a function of the concentration (Table 1). The molecular weight of $\gamma$ PGA somewhat influenced the activity; the activity in the presence of $\gamma \mathrm{PGA}-500$ was a little larger than that in $\gamma$ PGA-50. In case of the $\gamma$ PGA concentration of $3.0 \%$, on the other hand, the activity decrease was found in comparison with that in the $\gamma$ PGA concentration of $2.0 \%$, and the reduction ratio was much larger for $\gamma \mathrm{PGA}-500$. This is probably due to the dramatic viscosity increase of the reaction mixture. The viscosity values of the mixture of $\gamma$ PGA-500 and CA with 2.0 and $3.0 \%$ of $\gamma$ PGA-500 were 7.8 and $10.5 \mathrm{cP}$, respectively. It was reported that the high viscosity of the reaction media hampered the activity of lactate dehydrogenase and ATPase. ${ }^{41,42}$

In order to verify the effects of $\gamma \mathrm{PGA}$ on the enhancement of the activity of CA, the Michaelis-Menten kinetics for the CA-catalyzed hydrolysis of $p \mathrm{NPA}$ were carried out in the fixed $\gamma \mathrm{PGA}$ concentration of $0.50 \%$ at $25^{\circ} \mathrm{C}$. Figure 3 shows the relationships between the concentration of substrate $([\mathrm{S}])$ and the initial reaction velocity $(v)$ in the absence and presence of $\gamma$ PGA. The reaction in the presence of $\gamma$ PGA proceeded faster than that without $\gamma$ PGA and the larger 
Table 1 Effect of molecular weight and concentration of $\gamma \mathrm{PGA}$ on enzyme activity

\begin{tabular}{lccc}
\hline Enzyme & $\begin{array}{c}\text { Molecular weight of } \\
\gamma P G A(k D a)\end{array}$ & $\begin{array}{c}\text { Concentration } \\
(\%)\end{array}$ & $\begin{array}{c}\text { Enhanced } \\
\text { ratio }\end{array}$ \\
\hline CA & 50 & 0.010 & 0.10 \\
CA & 50 & 0.30 & 7.0 \\
CA & 50 & 0.50 & 18 \\
CA & 50 & 1.0 & 25 \\
CA & 50 & 2.0 & 40 \\
CA & 50 & 3.0 & 24 \\
CA & 500 & 0.010 & 1.2 \\
CA & 500 & 0.30 & 13 \\
CA & 500 & 0.50 & 19 \\
CA & 500 & 1.0 & 28 \\
CA & 500 & 2.0 & 48 \\
CA & 500 & 3.0 & -7.1 \\
Lipase & 50 & 0.50 & 21 \\
$\alpha-$ Amylase & 50 & 0.50 & 38
\end{tabular}

Abbreviations: CA, carbonic anhydrase; $\gamma \mathrm{PGA}$, poly $(\gamma$-glutamic acid).

${ }^{\text {a}}$ For relative activity.

bData at $55^{\circ} \mathrm{C}$

'Data at $25^{\circ} \mathrm{C}$.

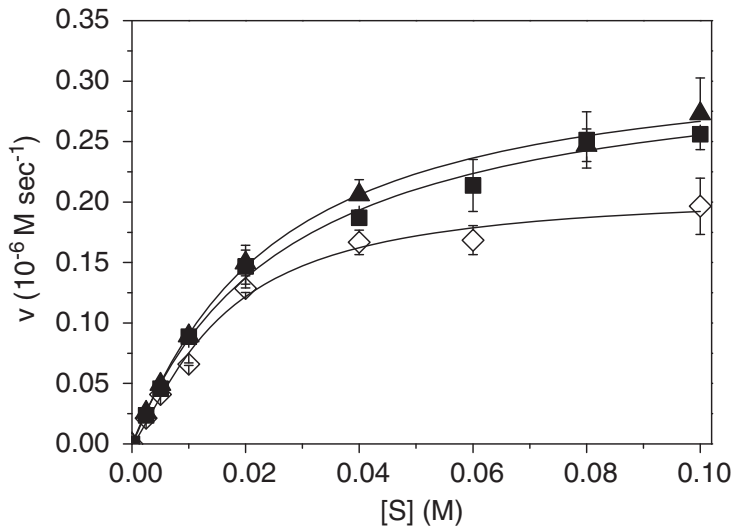

Figure 3 Relationships between the substrate concentration and the initial reaction velocity in the CA-catalyzed hydrolysis of pNPA in the absence or presence of $\gamma$ PGA-50 and $\gamma$ PGA-500 $(n=3) ; \diamond:$ no additive; $\mathbf{\square}: \gamma \mathrm{PGA}-50$; $\Delta$ : $\gamma$ PGA-500. The concentration of $\gamma$ PGA-50 was fixed as $0.50 \%$.

molecular weight $\gamma$ PGA was slightly more efficient to catalyze the reaction.

Table 2 summarizes the kinetic parameters determined from the Lineweaver-Burk plots (data not shown). Both values of $K_{\mathrm{m}}$ and $k_{\text {cat }}$ obtained without $\gamma$ PGA-50 were smaller than those in the presence of $\gamma$ PGA and the effect of the molecular weight of $\gamma$ PGA was relatively small. The catalytic efficiency $k_{\text {cat }} / K_{\mathrm{m}}$ in the presence of $\gamma \mathrm{PGA}$ was a little larger than that without $\gamma$ PGA and the highest efficiency was observed in the presence of $\gamma$ PGA-500. These results indicate that the improved activity of CA by $\gamma$ PGA is ascribed to the enormous increase of the reaction rate in spite of the decrease of the binding ability by the addition of $\gamma$ PGA

As shown above, $\gamma$ PGA improved the catalytic activity of CA, which may be due to the interaction between $\gamma$ PGA and CA. FITC-labeled proteins are often used for the mechanistic analysis to elucidate the interaction of proteins with target molecules. Thus, FITC-CA was prepared and fluorescence spectra of a mixture of FITC-CA and various water-soluble polymers were measured (Figure 4). The
Table 2 Kinetic parameters of $p$ NPA hydrolysis by CA

\begin{tabular}{llcc}
\hline Additive & $\mathrm{K}_{m}(\mathrm{~mm})$ & $\mathrm{k}_{\text {cat }}\left(\mathrm{s}^{-1}\right)$ & $\mathrm{k}_{\text {cat }} / \mathrm{K}_{m}\left(\mathrm{~s}^{-1} \mathrm{~mm}^{-1}\right)$ \\
\hline None & $2.1 \times 10^{-3}$ & $2.4 \times 10^{5}$ & $1.1 \times 10^{8}$ \\
$\gamma \mathrm{PGA}-50$ & $2.8 \times 10^{-3}$ & $3.3 \times 10^{5}$ & $1.2 \times 10^{8}$ \\
$\gamma \mathrm{PGA}-500$ & $2.7 \times 10^{-3}$ & $3.4 \times 10^{5}$ & $1.3 \times 10^{8}$ \\
\hline
\end{tabular}

Abbreviations: CA, carbonic anhydrase; $p$ NPA, $p$-nitrophenyl acetate; $\gamma$ PGA, poly $(\gamma$-glutamic acid).

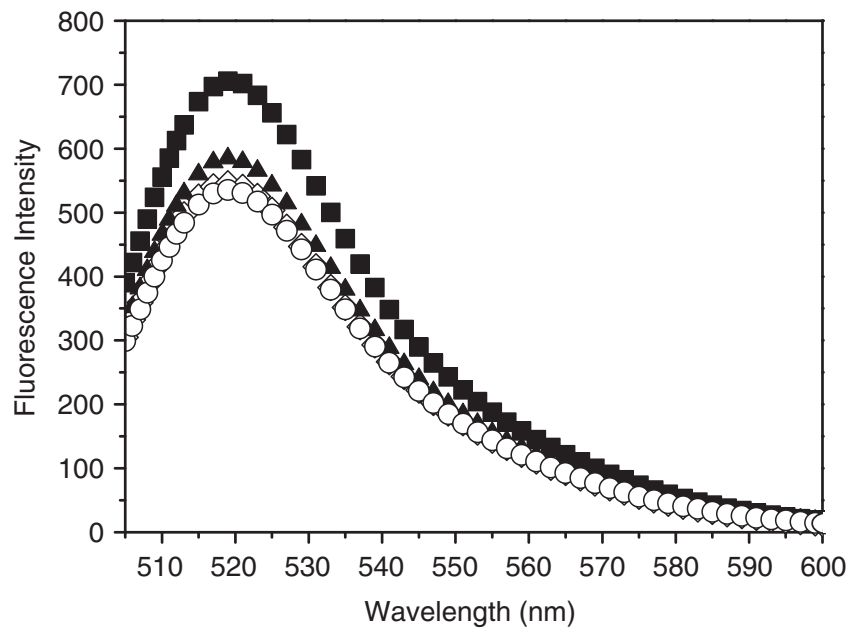

Figure 4 Fluorescence spectra of a mixture of FITC-labeled CA without and with water-soluble polymers; $\diamond$ : no additive; $\mathbf{\square}$ : $\mathrm{PGA}-50 ; \bigcirc: \mathrm{HA} ; \boldsymbol{\Delta}$ : PEG.

molar ratio of FITC to CA determined by ultraviolet-visible spectroscopy was 1.3; thus, the surface properties of FITC-labeled might be close to CA itself.

In all cases examined, the spectrum pattern was very similar to each other and the largest fluorescence intensity was observed at $520 \mathrm{~nm}$. The largest intensity in the spectrum of FITC-CA without any additives was almost the same as that with hyaluronic acid and a little smaller than that with PEG. On the other hand, the remarkable increase of the largest intensity was found by the addition of $\gamma$ PGA, indicating that the surrounding environment of the FITC moiety becomes hydrophobic in the presence of $\gamma$ PGA. ${ }^{43,44}$ These data suggest that $\gamma$ PGA wraps FITC-CA by their physical interaction to locate FITC-CA in the hydrophobic region, which may lead to the improved activity of CA by $\gamma$ PGA. Furthermore, 1-anilinonaphthalene-8-sulfonate was used as hydrophobic probe for the investigation with $\gamma$ PGA. The increase of its fluorescence intensity was found by the addition of the $\gamma$ PGA, which supports the hydrophobic region of $\gamma$ PGA. The net charge and isoelectric point ( $\mathrm{pI}$ ) of CA were -1.2 and 6.7 , respectively; thus CA was almost neutral at $\mathrm{pH} 7$, suggesting the weak electrostatic interaction between $\gamma$ PGA and CA.

\section{Effect of $\gamma$ PGA on the activity of lipase and $\alpha$-amylase and their} thermal denaturation

We have examined whether $\gamma$ PGA was effective for the activity enhancement of other enzymes (lipase and $\alpha$-amylase) besides CA (Figure 5). Lipase used in this study was a heat-resistant enzyme and showed the optimum activity at $55^{\circ} \mathrm{C}$; thus, the enhanced effect was examined at $55^{\circ} \mathrm{C}$. The activity of $\alpha$-amylase was measured at $25^{\circ} \mathrm{C}$. The activity of both enzyme improved by the addition of $\gamma \mathrm{PGA}$ 

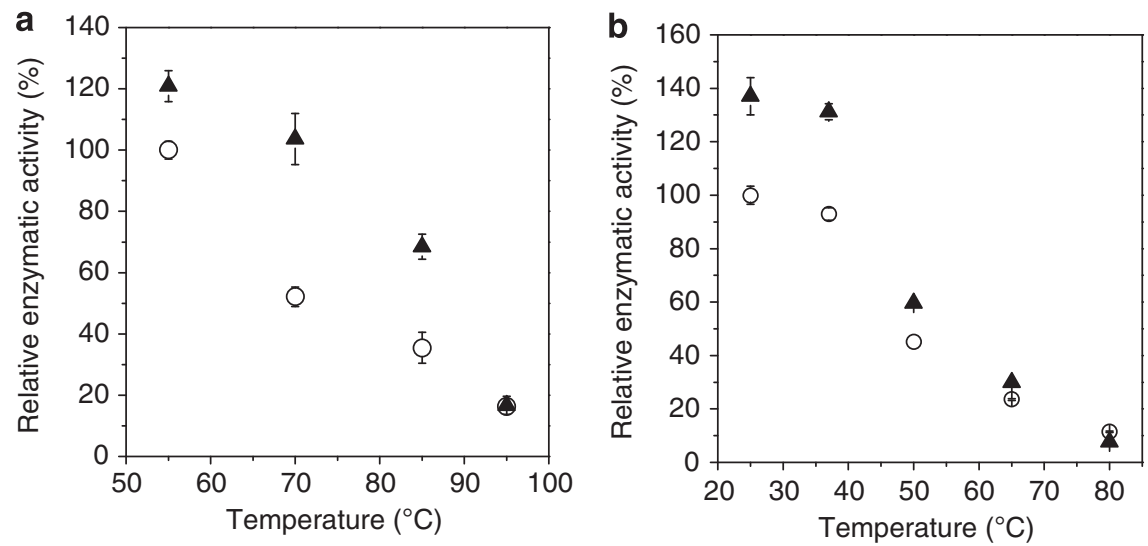

Figure 5 Relative enzyme activity in the absence or presence of $0.50 \% \gamma$ PGA-50 ( $n=3$ ); (a) lipase, (b) $\alpha$-amylase; $\bigcirc:$ no additive; $\mathbf{\Delta}: \gamma \mathrm{PGA}-50$.

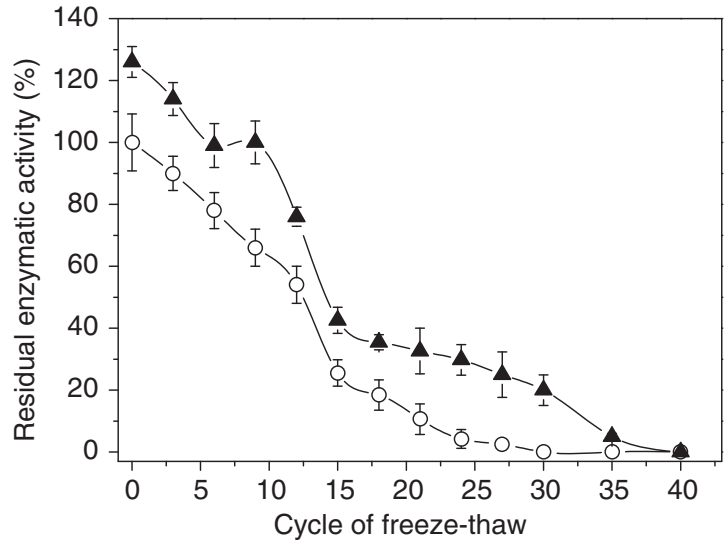

Figure 6 Remaining relative activity of CA without and with $\gamma \mathrm{PGA}-50$ after freeze-thaw process $(n=3)$; $\bigcirc$ : no additive; $\mathbf{\Delta}: 1.0 \% \gamma \mathrm{PGA}-50$.

(Table 1 ). The enhanced ratio of $\alpha$-amylase for the relative activity was $38 \%$, which was higher than that of lipase.

The thermal denaturation effect for these enzymes by $\gamma$ PGA has been examined. The thermal treatment was performed at different temperatures. For lipase, the enzyme activity in the presence of $\gamma$ PGA50 was higher than that in the absence $\gamma$ PGA- 50 between 55 and $85^{\circ} \mathrm{C}$. It is to be noted that the relative activity was beyond $100 \%$ even at $70{ }^{\circ} \mathrm{C}$ by the addition of $\gamma \mathrm{PGA}-50$. More than twofold activity was found at 70 and $85^{\circ} \mathrm{C}$ in comparison with that without $\gamma$ PGA. For $\alpha$-amylase, the activity in the presence of $\gamma \mathrm{PGA}-50$ at 25 and $37^{\circ} \mathrm{C}$ was much higher than that without $\gamma \mathrm{PGA}-50$. Even at $50^{\circ} \mathrm{C}$, the higher activity was found with $\gamma$ PGA-50. These data indicate that $\gamma$ PGA was effective to protect lipase and $\alpha$-amylase by the thermal denaturation.

\section{Protection effect of $\gamma$ PGA for freeze-thaw stress}

It is reported that freeze-thaw processes seriously damage proteins irreversibly. ${ }^{45,46}$ Here, the protection effect of $\gamma$ PGA for the repeated freeze-thaw process was examined by using CA as model enzyme. In the absence of $\gamma$ PGA-50, the activity of CA was about $65 \%$ after nine cycles and completely lost after 27 cycles (Figure 6). On the other hand, the activity was beyond $100 \%$ after nine cycles in the presence of $\gamma$ PGA and the activity remained even after 35 cycles. These data suggest that $\gamma$ PGA prevents denaturation of enzymes from stress of freeze-thaw process.

\section{CONCLUSION}

In this study, $\gamma$ PGA was found to strongly influence the enzyme activity and stability. The activity of CA, lipase and $\alpha$-amylase was improved by the addition of a small amount of $\gamma$ PGA. Generally, the thermal treatment of enzymes decreased their activity, whereas the presence of $\gamma \mathrm{PGA}$ suppressed the activity decrease in the thermal treatment at high temperature to some extent for lipase and $\alpha$-amylase. Furthermore, $\gamma$ PGA was also efficient for the suppression of denaturation of enzymes during the freeze-thaw process. These data strongly suggest that $\gamma$ PGA has high potential as enhancer of enzyme activity and stabilizer for thermal treatment and freeze-thaw process.

The kinetic study in the system of CA and $\gamma$ PGA implied that the enhancement of the enzyme activity was due to the increase of the reaction rate and the presence of $\gamma$ PGA prevented the binding ability of the substrate. The formation of the specific complex between CA and $\gamma$ PGA, in which CA was located in the hydrophobic region, was shown by the analysis using fluorescence probe-labeled CA. These results suggest that the interaction between $\gamma$ PGA and enzyme proteins induces the conformational change of enzymes, leading to the activity enhancement and stability improvement for environmental stresses.

$\gamma$ PGA is an inexpensive biopolymer produced in industrial scale, and hence, it is highly expected to be an attractive additive in the field of enzyme industry. Our present finding that $\gamma \mathrm{PGA}$ was effective for the improvement of the enzyme activity as well as that of the enzyme stability for thermal denaturation and stress of freeze-thaw process is useful for industrial enzyme engineering. Further investigations including mechanistic study on the interaction of $\gamma$ PGA and proteins and industrial applications of $\gamma$ PGA for additives of enzyme products are under way in our laboratories.

1 Kirk, O., Borchert, T. V. \& Fuglsang, C. C. Industrial enzyme applications. Curr. Opin. Biotechnol. 13, 345-351 (2002).

2 Schmid, A., Hollmann, F., Park, J. B. \& Bühler, B. The use of enzymes in the chemical industry in Europe. Curr. Opin. Biotechnol. 13, 359-366 (2002).

3 Ó’Fágáin, C. Enzyme stabilization-recent experimental progress. Enzyme Micro. Technol. 33, 137-149 (2003). 
4 Mateo, C., Palomo, J. M., Fernandez-Lorente, G., Guisan, J. M. \& Fernandez-Lafuente, R. Improvement of enzyme activity, stability and selectivity via immobilization techniques. Enzyme Micro. Technol. 40, 1451-1463 (2007).

$5 \mathrm{Kim}$, J., Grate, J. W. \& Wang, P. Nanostructures for enzyme stabilization. Chem. Eng. Sci. 61, 1017-1026 (2006).

6 Ispas, C., Sokolov, I. \& Andreescu, S. Enzyme-functionalized mesoporous silica for bioanalytical applications. Anal. Bioanal. Chem. 393, 543-554 (2009).

7 Bagi, K., Simon, L. M. \& Szajáni, B. Immobilization and characterization of porcine pancreas lipase. Enzyme Micro. Technol. 20, 531-535 (1997).

8 Yamane, T., Ichiryu, T., Nagata, M., Ueno, A. \& Shimizu, S. Intramolecular esterification by lipase powder in microaqueous benzene: factors affecting activity of pure enzyme. Biotech. Bioeng. 36, 1063-1069 (1990).

9 Mozhaev, V. V., Melik-Nubarov, N. S., Sergeeva, M.V., Šikšnis, V. \& Martinek, K. Strategy for stabilizing enzymes part one: increasing stability via their multi-point interaction with a support. Biocatalysis 3, 179-187 (1990).

10 Govardhan, C. P. Crosslinking of enzymes for improved stability and performance. Curr. Opin. Biotechnol. 10, 331-335 (1999).

11 Lee, M. Y. \& Dordick, J. S. Enzyme activation for nonaqueous media. Curr. Opin. Biotechnol. 13, 376-384 (2002).

12 Klibanov, A. M. Improving enzymes by using them in organic solvents. Nature 409, 241-246 (2001).

13 Adlercreutz, P. Activation of enzymes in organic media at low water activity by polyols and saccharides. Biochim. Biophys. Acta. 1163, 144-148 (1993).

14 Arakawa, T. \& Timasheff, S. N. Stabilization of protein structure by sugars. Biochemistry 21, 6536-6544 (1982).

15 Yoon, S. H. \& Robyt, J. F. Activation and stabilization of 10 starch-degrading enzymes by triton X-100, polyethylene glycols, and polyvinyl alcohols. Enzyme Micro. Technol. 37, 556-562 (2005).

16 Simon, L. M., Kotormán, M., Garab, G. \& Laczkó, I. Effects of polyhydroxy compounds on the structure and activity of $\alpha$-chymotrypsin. Biochem. Biophys. Res. Commun. 293, 416-420 (2002).

17 Guo, W. \& Mabrouk, P. A. Raman evidence that the lyoprotectant poly(ethylene glycol) does not restore nativity to the heme active site of horseradish peroxidase suspended in organic solvents. Biomacromolecules 3, 846-849 (2002).

18 Andersson, M. M. \& Hatti-Kaul, R. Protein stabilising effect of polyethyleneimine. J. Biotechnol. 72, 21-31 (1999).

19 Ulmer, K. M. Protein engineering. Science 219, 666-671 (1983).

20 Eijsink, V. G. H., Bjørk, A., Gåseidnes, S., Sirevåg, R., Synstad, B., Burg, B. \& Vriend, G. Rational engineering of enzyme stability. J. Biotechnol. 113, 105-120 (2004).

21 Arnold, F. H., Wintrode, P. L., Miyazaki, K. \& Gershenson, A. How enzymes adapt: lessons from directed evolution. Trends Biochem. Sci. 26, 100-106 (2001).

22 Brannigan, J. A. \& Wilkinson, A. J. Protein engineering 20 years on. Nature 3, 964-970 (2002).

23 Lehmann, M. \& Wyss, M. Engineering proteins for thermostability: the use of sequence alignments versus rational design and directed evolution. Curr. Opin. Biotechnol. 12, 371-375 (2001).

24 Roelants, G. E. \& Goodman, J. W. Immunochemical studies on the poly- $\gamma$-D-glutamyl capsule of Bacillus anthracis. IV. The association with peritoneal exudate cell ribonucleic acid of the polypeptide in immunogenic and nonimmunogenic forms. Biochemistry 7, 1432-1440 (1968).

25 Ko, Y. H. \& Gross, R. A. Effects of glucose and glycerol on $\gamma$-poly(glutamic acid) formation by Bacillus licheniformis ATCC 9945a. Biotechnol. Bioeng. 57, 430-437 (1998).

26 Richard, A. \& Margaritis, A. Poly(glutamic acid) for biomedical applications. Crit. Rev. Biotech. 21, 219-232 (2001).

27 Sung, M. H., Park, C., Kim, C. J., Poo, H., Soda, K. \& Ashiuchi, M. Natural and edible biopolymer poly- $\gamma$-glutamic acid: synthesis, production, and applications. Chem. Record 5, 352-366 (2005).
28 Kim, T. W., Lee, T. Y., Bae, H.C., Hahm, J. H., Kim, Y. H., Park, C., Kang, T. H., Kim, C. J., Sung, M. H. \& Poo, H. Oral administration of high molecular mass poly- $\gamma$-glutamate induces NK cell-mediated antitumor immunity. J. Immun. 179, 775-780 (2007).

29 Park, C., Choi, Y. H., Shin, H. J., Poo, H., Song, J. J., Kim, C. J. \& Sung, M. H. Effect of high-molecular-weight poly- $\gamma$-glutamic acid from Bacillus subtilis (chungkookjang) on Ca solubility and intestinal adsorption. J. Microbiol. Biotechnol. 15, 855-858 (2005).

30 Lee, T. Y., Kim, Y. H., Yoon, S. W., Choi, J. C., Yang, J. M., Kim, C. J., Schiller, J. T., Sung, M. H. \& Poo, H. Oral administration of poly-gamma-glutamate induces TLR4and dendritic cell-dependent antitumor effect. Cancer Immunol. Immunother. 58, 1781-1794 (2009).

31 Nomura, Y., Sasaki, Y., Takagi, M., Narita, T., Aoyama, Y. \& Akiyoshi, K. Thermoresponsive controlled association of protein with a dynamic nanogel of hydrophobized polysaccharide and cyclodextrin: heat shock protein-like activity of artificial molecular chaperone. Biomacromolecules 6, 447-452 (2005).

32 Simon, L. M., László, K., Vértesi, A., Bagi, K. \& Szajáni, B. Stability of hydrolytic enzymes in water-organic solvent systems. J. Mol. Cat. B: Enzym. 4, 41-45 (1998).

33 Pocker, Y. \& Storm, D. R. The catalytic versatility of erythrocyte carbonic anhydrase IV kinetic studies of enzyme-catalyzed hydrolyses of $p$-nitrophenyl esters. Biochemistry 7, 1202-1214 (1968).

34 Tu, C., Thomas, H. G., Wynns, G. C. \& Silverman, D. N. Hydrolysis of 4-nitrophenyl acetate catalyzed by carbonic anhydrase III from bovine skeletal muscle. J. Biol. Chem. 261, 10100-10103 (1986).

35 Akiyoshi, K., Sasaki, Y. \& Sunamoto, J . Molecular chaperone-like activity of hydrogel nanoparticles of hydrophobized pullulan: thermal stabilization with refolding of carbonic anhydrase B. Bioconjugate Chem. 10, 321-324 (1999).

36 Fersht, A Structure and Mechanism in Protein Science: A Guide to Enzyme Catalysis and Protein Folding, Ch. 2,103-131 (W. H. Freeman and Co.: New York, 1998).

37 Bastida, A., Sabuquillo, P., Armisen, P., Fernández-Lafuente, R., Huguet, J. \& Guisán, J. M. A single step purification, immobilization, and hyperactivation of lipases via interfacial adsorption on strongly hydrophobic supports. Biotechnol. Bioeng. 58, 486-493 (1998).

38 López-Serrano, P., Cao, L., Rantwijk, F. \& Sheldon, R. A. Cross-linked enzyme aggregates with enhanced activity: application to lipases. Biotechnol. Lett. 24, 1379-1383 (2002)

39 Dedmon, R. E., Holmes, A. W. \& Deinhardt, F. Preparation of fluorescein isothiocyanate-labeled $\gamma$-globulin by dialysis, gel filtration, and ion exchange chromatography in combination. J. Bacteriol. 89, 734-739 (1965).

40 Shu, F., Kobayashi, H., Fukudome, K., Tsuneyoshi, N., Kimoto, M. \& Terao, T. Activated protein C suppresses tissue factor expression on U937 cells in the endothelial protein C receptor-dependent manner. FEBS Lett. 477, 208-212 (2000).

41 Demchenko, A. P., Rusyn, O. I. \& Saburova, E. A. Kinetics of the lactate dehydrogenase reaction in high-viscosity media. Biochim. Biophys. Acta. 998, 196-203 (1989).

42 Sampedro, J. G. \& Uribe, S. Trehalose-enzyme interactions result in structure stabilization and activity inhibition. The role of viscosity. Mol. Cellular Biochem. 256, 319-327 (2004).

43 Aoyagi, S., Imai, R., Sakai, K. \& Kudo, M. Reagentless and regenerable immunosensor for monitoring of immunoglobulin $\mathrm{G}$ based on non-separation immunoassay. Biosen. Bioelec. 18, 791-795 (2003).

44 Kim, M. S., Seo, K. S., Khang, G. \& Lee, H.B. Preparation of a gradient biotinylated polyethylene surface to bind streptavidin-FITC. Bioconjugate Chem. 16, 245-249 (2005).

45 Park, J. I., Grant, C. M., Davies, M. J. \& Dawes, I. W. The cytoplasmic Cu, Zn superoxide dismutase of Saccharomyces cerevisiae is required for resistance to freeze-thaw stress. J. Biol. Chem. 273, 22921-22928 (1998).

46 Pikal-Cleland, K. A., Rodríguez-Hornedo, N., Amidon, G. L. \& Carpenter, J. F. Protein denaturation during freezing and thawing in phosphate buffer systems: monomeric and tetrameric $\beta$-galactosidase. Arch. Biochem. Biophys. 384, 398-406 (2000). 